\title{
Three New distributional records of Pen Shells (Bivalvia: Pinnidae) from Seagrass beds of Palk Bay Area in Tamil Nadu
}

\author{
Chelladurai Stella ${ }^{1}$, Packiam Paul ${ }^{1}$ and Chelladurai Ragunathan ${ }^{2}$
}

1- Department of Oceanography and Coastal Area Studies ,Alagappa University,Thondi Campus623409,Tamil Nadu ,India ; stella2004@ rediffmail.com

2- Zoological Survey of India ,Andaman and Nicobar Island Regional centre, Port Blair, 744102,Andaman and Nicobar Island

Abstract

The new occurrence of three species of bivalves from Pinnidae family is recorded for the first time from Palk Bay area based on a live organisms and dead shells collected from the intertidal area. All the three species are under the family of Pinnidae, Pinna bicolor, Pinna deltodes and Pinna incurva .In seagrass bed of Thondi Coast, all the species of Pen shells Pinna bicolor, Pinna deltodes and Pinna incurva were embedded in muddy sand and found associated with seagrasses at intertidal area. It was also found buried in hard substratum associated with living zoanthids and soft coral. The collected specimens were identified as, (1) Pinna bicolor, (2) Pinna deltodes and (3) Pinna incurva by using both morphometric and meristic characters. The paper described the taxonomic status and the description of the three species of bivalves collected from Palk Bay areas.

Keywords: Pinna bicolor, Pinna deltodes, Pinna incurva, morphometry, bivalves

Resumen

Se reportó la presencia de tres nuevas especies de bivalvos en el último tiempo en la zona de la bahía de Palk basado en el hallazgo de conchas nuevas y organismos vivos en la zona intermareal. Todas las tres especies están en la familia Pinnidae, Pinna bicolor, Pinna deltodes y Pinna incurva. En la zona de pastizales de la costa de Thondi, las tres especies de conchas shells Pinna bicolor, Pinna deltodes yPinna incurva se encontraron embebidas en la arena fangosa y se encontraron asociadas a pastos marinos en la zona intermareal. También se encontraron en el estrato duro asociadas a zoantidos y corales blandos. Los especimenes colectados fueron identificados como: (1) Pinna bicolor, (2) Pinna deltodes y(3) Pinna incurva mediante caracteres morfométricos y merísticos. El artículo describe el estado taxonómico y la descripción de las tres especies de bivalvos colectados en el área de la bahía de Palk.

Palabras clave: Pinna bicolor, Pinna deltodes, Pinna incurva, morfometría, bivalvos 
Introduction

Pen shells are one of the important fisheries resources and it can easily be established as important commercial species. Pinna and Atrina are used for different purposes by many different cultures around the world (Velasco, 1998). The fine golden-brown byssal fibers of the Mediterranean Pinna shells were used to weave the legendary Cloth-of-Gold (Turk, 1982). Much works are involved to harvest of enough Pinna species and to process the fiber for weaving and the cloth could be afforded only by royalty (Wang, 1964). Marine shells of the family Pinnidae are a popular food source and high commercial value in a number of Asia-Pacific countries. Pinnidae has a noticeable economic importance in the western Pacific. They are actively collected for food in Japan and surrounding areas, as well as in Polynesia and several other Indo-Pacific island groups (Yu et al., 2004). Velasco (1998), reported that their posterior abductor mussel is widely marketed domestically. The Pen shell meat may reach a price as high as 150 mexican pesos/kg (US9. 40/pound). The interior of the shell is occasionally used for jewelry, but this is a very minor contributor to the economy. The Pinnidae or Pen shells are widely distributed in the Indo-Pacific regions and also found in Mediterranean and American waters. Atrina and Pinna species exist as meta populations, composed of small groups or patches of individuals. (Butler, 1987; Munguia, 2004; Rosewater, 1961; Zavodnik et al.,1991). Richardson et al., (1998) studied Pinna carnea and Pinna nobilis in Mediterranean . Pen shells are relatively common at the sandy substrate of the seagrass beds (Posidoniaoceanica and Cymodocea nodosa ), lagoons and coral rubble areas (Anonymous, 2003 ; Luc Solandt, J,1999). Butler and Keough, (1981) studied the distribution and abundance of benthic organisms present in particular area of Malaysia. Torigoe (1985) reported the two types pen shell - Scaly type and smooth type are defined by the presence or absence of squamation of the shell surface. Yokogawa, (1996) studied that the two types of Pen shells are taxonomically distinguished by comparison of morphology and isozymic analyses. Dietl \& Alexander (2005) and Yonge (1953) studied the outer prismatic layer of shell can be reformed by the mantle which secretes the shell. Pinna bicolor was found previously in littoral sand and muddy habitats (Lamprell \& Whitehead 1992; Beer \& Southgate 2006). Rosewater (1961) reported that it was also found embedded in muddy sand and reef flats in shallow water of 1 to 2 fathoms in depth. Scheltema (1983) reported that Pinna bicolor occurred on the mixed sand cobble flats in Townsville, Queensland, Australia. In the present study describes about the taxonomy status and description of pen shells collected from the seagrass beds of Thondi Coast. These areas were chosen because of the natural abundance of pen shells that live in association with the seagrasses. In Palk Bay, so far there is no data available on occurrence and distribution of the Pen shell. Hence the present study provide the taxonomic status and description of Pen shell species from Thondi Coast. 
Materials and Methods

During the Quaternary period the Palk bay is believed to have originated establishing a close connection between Southern Gulf of Mannar and the northern Bay of Bengal. This seen in the map with in the latitude of $09^{\circ}$ and $10^{\circ} \mathrm{N}$ and longitude of $79^{\circ}$ and $80^{\circ} \mathrm{E}$ (Fig 1). The Palk bay is influenced mainly by the northeast monsoon. The Palk Bay is endowed with rich living and non - living resources. The Palk bay area is familiar for the presence of economically important renewable resources like seaweeds, shrimps, lobsters, holothurians, mollusks and fin fishes. The coastal habitats here are under threat from development activities and overexploitation of natural resources.Therefore the present initiative was taken to study the taxonomic status and description of Pen shell in Thondi coast .Thondi coastal area is situated in the Palk Bay in Tamil Nadu.. The rainfalls in Thondi region are mainly due to North East and South West monsoon. Thondi coast has a very minimal wave action. All the species of Pen shells Pinna bicolor, Pinna deltodes and Pinna incurva were embedded in muddy sand and found associated with the seagrass beds in the inter-tidal area. It was also found buried in hard substratum associated with living zoanthids and soft coral. Pinna species were found to be exposed to direct sunlight for one to two hours during the low tide.

A survey was conducted in Palk Bay area (latitude $09^{\circ}$ and $10^{\circ}$ and longitudinal $79^{\circ}$ and $80^{\circ}$ ) during September 2010 to August 2011 as this region provides ample diversity of Pen shells. The shells were collected manually and transferred immediately to the laboratory for further taxonomic identification. The collected specimens were stored in $10 \%$ formalin and body color attributes, shell length and shell height were recorded. Identification was mainly based on the external morphology of the shell. Further ,the following systematic reference were used as importance guides for the identification of the species concerned: Peter Dance (1992); Ramakrishna \& Day(2010); The complete encyclopedia of shells by R.H.DE. Bruyne (2003).WWW.microseashell.com.In Palk bay area so far no data available on the Pen shell diversity. All the three species belong to the Phylum Mollusca, Class Bivalvia, Order Pterioida and Family Pinnidae. The collected specimens were identified as, (1) Pinna bicolor, (2) Pinna deltodes and (3) Pinna Incurva by using both morphometric and meristic characters that includes; 1. Anterior to posterior adductor muscle length (APAML) 2. Posterior adductor muscle to posterior shell margin (PAMPSM) 3. Dorsal posterior margin length (DPML) 4. Dorsal margin length (DML) 5. Width length (WL) 6. Total length (TL) 7. Width of sulcus (WS) 8. Posterior adductor muscle to posterior dorsal narcreous layer (PAMPDNL) 9. Dorsal nacreous length (DNL). 


\section{DESCRIPTION OF THE SPECIES}

1. Pinna bicolor (Gmelin, 1791)

Classification

Phylum: Mollusca

Class: Bivalvia

Order: Pterioida

Family: Pinnidae

Genus:Pinna

Species: bicolor (Gmelin, 1791)

Synonyms of Pinna bicolor (Gmelin, 1791)

Pinna bicolor(Gmelin1791); Pinna atropurpurea,(Sowerby1825); Pinna deltodes(Menke 1843); Pinna trigonium (Dunker1852); Pinna electrina (Reeve1858); Pinna fumata (Hanely Reeve, 1858); Pinna madida (Reeve1858); Pinna mutica (Reeve1858); Pinna fimbriata (Reeve1858);

Pinna inermis (Tate, 1887); Pinna natalensis (Smith, 1906); Pinna isosceles (Hedley, 1924); Pinna scpsula (Hedley, 1924); Pinna densecostata (Turton1932); Exitopinna deltodes ultra (Iredala 1939)

Description : Pinna bicolor (Gmelin,1791), shell upto $370 \mathrm{~mm}$ in length and $166 \mathrm{~mm}$ in width, triangular in shape. Posterior margin of the shell concave and attenuated. Dorsal margin of the shell straight posteriorly and concave anteriorly and the ventral margin convex posteriorly and straight anteriorly. Nacreous layer was iridescent. The length of nacreous layer was $196 \mathrm{~mm}$ and the dorsal and ventral lobes of nacreous layer well separated by longitudinal sulcus and not forming deep ' $\mathrm{V}$ ' shape structure. Ventral lobe extended posteriorly than the dorsal lobe and near to sulcus. Posterior margin of dorsal and ventral lobes of nacreous layer forming truncate to slightly oblique in shape and the nacreous area occupied two-thirds of the valve. The length of posterior adductor muscle to posterior shell margin was $175 \mathrm{~mm}$ and the size of the Posterior adductor muscle was (45 $\mathrm{mm}$ ). The adductor muscle was never extended into ventral lobe. The length of anterior to posterior adductor muscle was $190 \mathrm{~mm}$. The anterior adductor muscle was small in size $(21 \mathrm{~mm})$ and this anterior adductor muscle was located anterior to end of longitudinal sulcus. In Pinna bicolor, it is translucent, yellowish and light horn to dark brownish purple in colour. (Figs. 1 and 2)

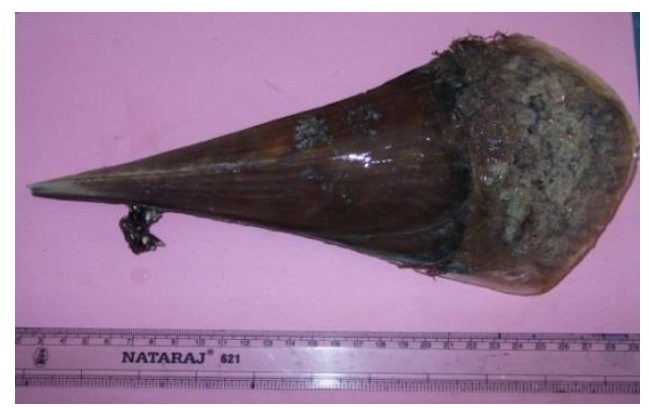

Fig. 1. Pinna bicolor 


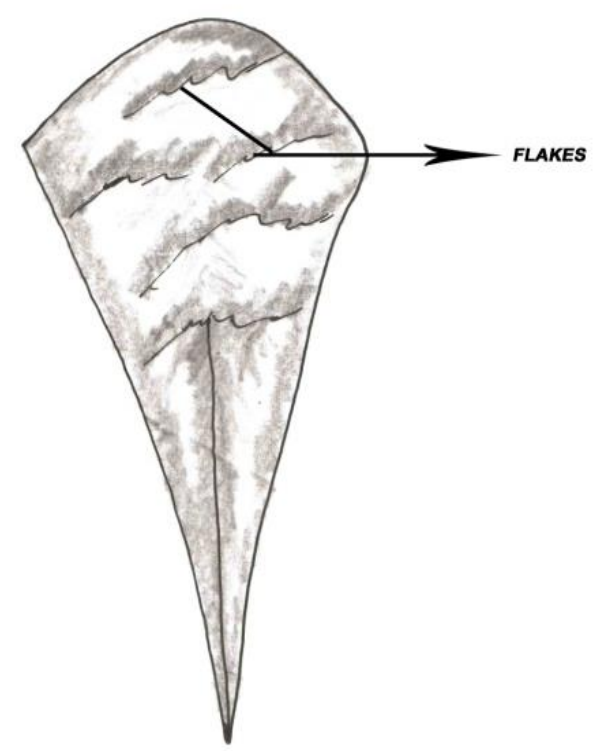

Dorsal side

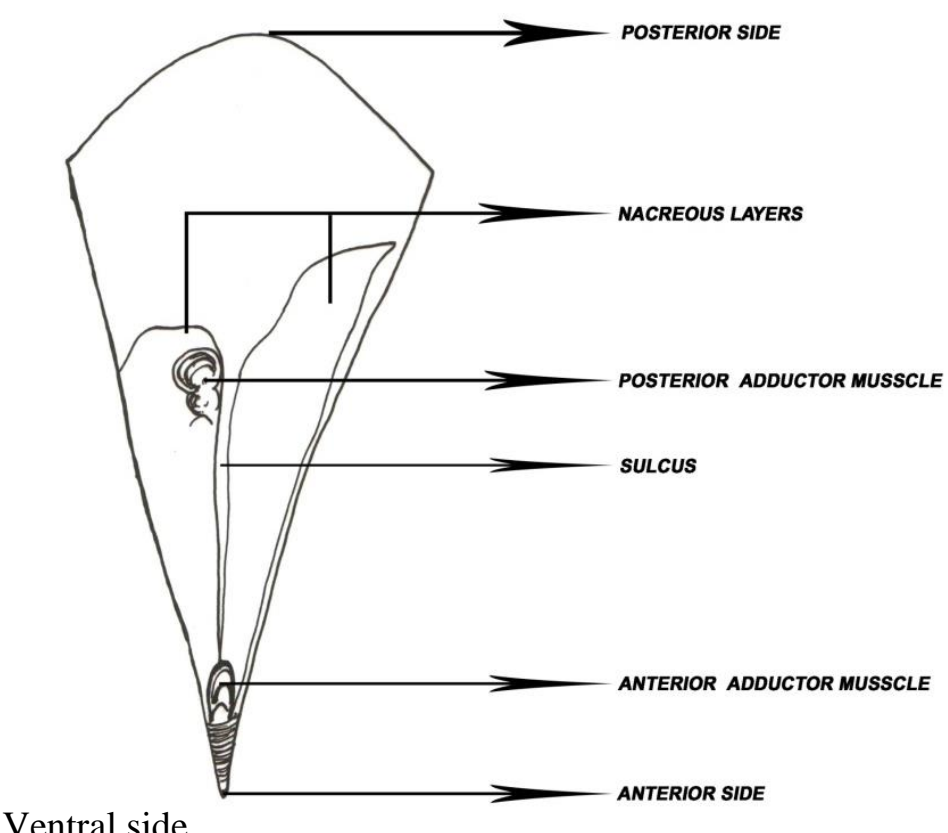

Ventral side

Fig. 2. Morphometric characters of Pen shell Pinna bicolor

\section{Pinna deltodes (Menke, 1843)}

\section{Classification}

Phylum: Mollusca.

Class: Bivalvia.

Order: Pterioida.

Family: Pinnidae.

Genus:Pinna.

Species:deltodes

Synonyms of Pinna deltodes (Menke, 1843)

Pinna deltodes ,(Menke, 1843); Pinna scapula, (Hedley 1924);Exitopinna deltodes (UltraIdedale 1939)

\section{Description}

Pinna deltodes (Menke, 1843), shell upto $230 \mathrm{~mm}$ in length and $112 \mathrm{~mm}$ in width. Shell width was about three-quarter of shell length. The shells extremely flared posteriorly and the width nearly equal to the length. Dorsal margin was larger than the ventral margin. Shell Posterior straight and anteriorly concave. Length of dorsal margin $193 \mathrm{~mm}$ and dorsal posterior margin $69 \mathrm{~mm}$ respectively. Ventral margin was posteriorly convex and concave anteriorly. Nacreous layer was 
iriesdescent and well separated longitudinal sulcus was $3 \mathrm{~mm}$. Sulcus separating dorsal and ventral nacreous lobes wide measuring $2 \mathrm{~mm}$. Dorsal lobe was longer than the ventral lobe. Dorsal lobes of nacreous $105 \mathrm{~mm}$ and posterior margin of dorsal and ventral lobes were truncated. Posterior adductor muscle was medium in size $20 \mathrm{~mm}$ and located near or touching on to posterior edge of dorsal lobe was $5 \mathrm{~mm}$. length of anterior to posterior adductor muscle was $97 \mathrm{~mm}$. The anterior adductor muscle was small to moderate in size, sub-apical and located just anterior to and of longitudinal sulcus. The colour of the shell was translucent, light horn to dark brownish purple. All specimens showed light horn to dark brownish purple in color. (Figs 3 and 4)

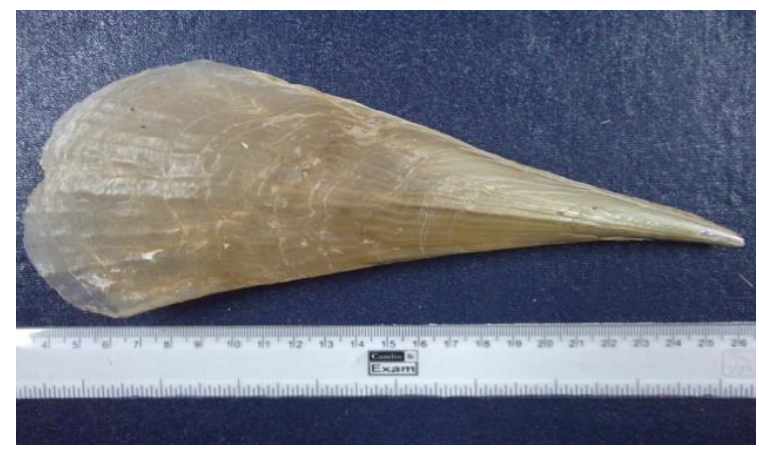

Fig. 3: Pinna deltodes

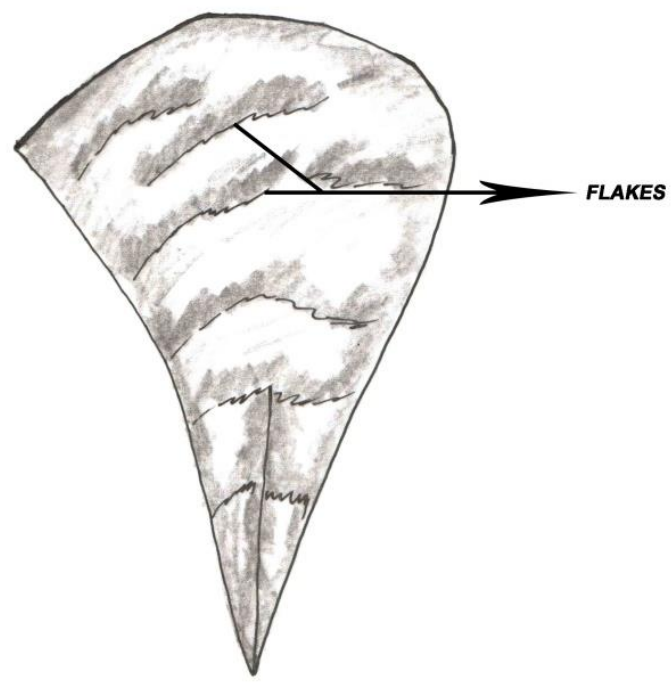

Dorsal side

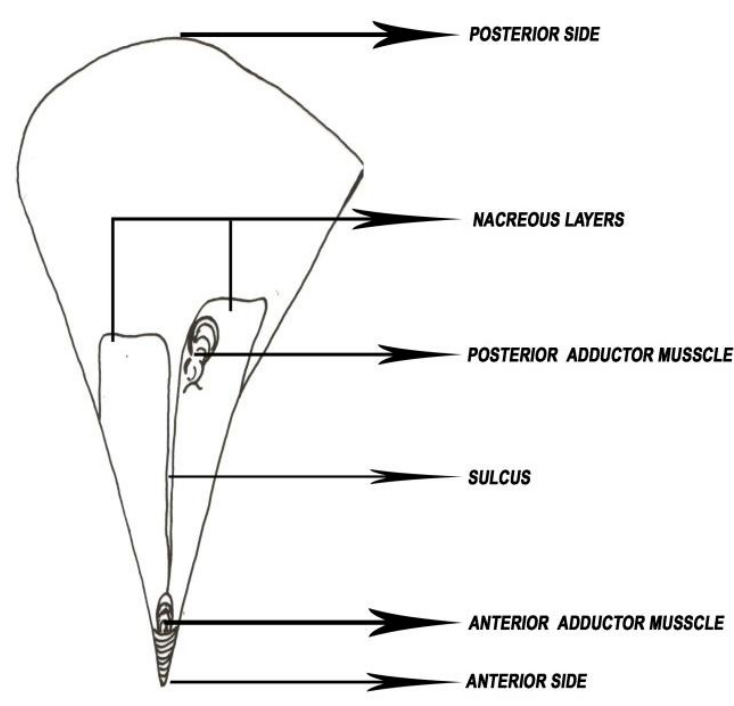

Ventral side

Fig. 4. Morphometric characters of pen shell Pinna deltodes 


\section{Pinna incurva (Gmelin, 1791)}

\section{Classification}

Phylum: Mollusca

Class: Bivalvia

Order: Pterioida

Family: Pinnidae

Genus: Pinna

Species: incurva

Synonyms of Pinna incurva (Gmelin, 1791)

Pinna incurva, (Gmelin 1791); Pinna incurva, (Sowerby 1825);Pinna incurvata, (Born 1778)

Pinna nobilis, (Rosewater 1961)

Description :Pinna incurva (Gmelin, 1791), shells upto $179 \mathrm{~mm}$ in length and $76 \mathrm{~mm}$ in width, respectively. Shell narrowly attenuated and wedge-shaped in outline and translucent. Radial sculpture hardly observable and consists of about six ribs limited to the posterior slope. Posterior margin extremely sloped from dorsal posterior edge to ventral side of anterior shape or rounded, subinflated, with a relatively weak longitudinal keel on the anterior half of the shell. Ventral margin was posteriorly convex and straight anteriorly. Dorsal margin straight from anterior to posterior. Nacreous layer iridescent, occupying most of the anterior half of the shell and divided along most of its length into two lobes by a narrow longitudinal sulcus was $1 \mathrm{~mm}$. Dorsal and ventral lobes of the posterior margins are obliquely truncate, sloping from sulcus towards ventral shell margins, forming with this equal posterior extension a wide and deep V shaped. Dorsal and ventral lobes are obliquely truncated and sloping from sulcus. The length of dorsal nacreous layer was $62 \mathrm{~mm}$. Posterior adductor muscle was medium in size, sub-terminal on ventral portion of dorsal nacreous lobe with size $15 \mathrm{~mm}$ in diameter. The adductor muscle scar was not touching the posterior margin of dorsal nacreous lobe was $5 \mathrm{~mm}$. Anterior adductor muscle was moderately small in size, sub-apical, the sulcus nearly reaching it. Colour of the shell light reddish brown to yellowish-horn colour. (Figs 5 and 6)

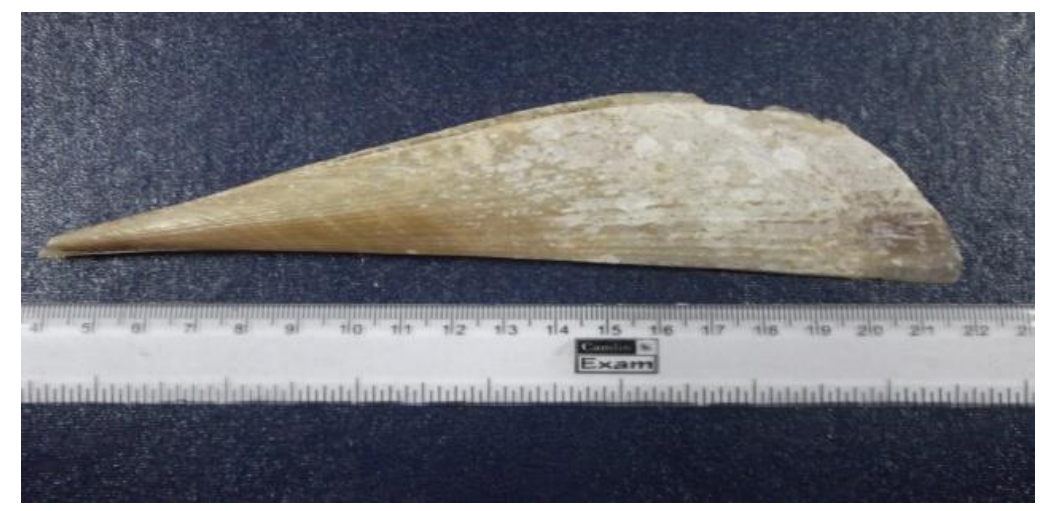

Fig. 5 : Pinna incurva 


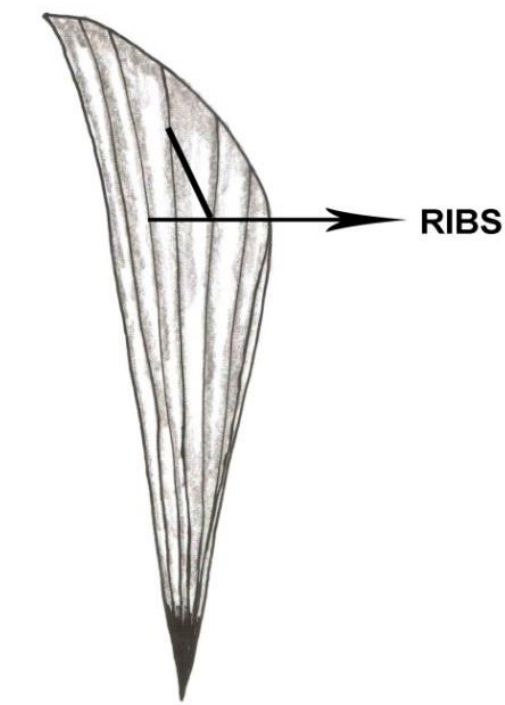

Dorsal side

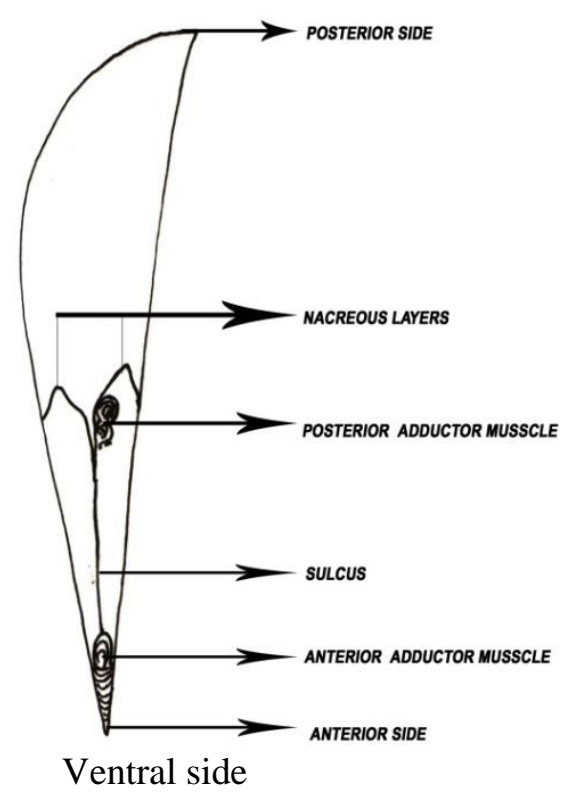

Fig. 4. Morphometric characters of pen shell Pinna incurva

\section{Remarks}

Morphological characteristic features of the three species of Pen shell differ from the shape and colour of the shell, location of the nacreous lobe and the external surface of the shell and the similarities were observed in the shape of the sulcus, location and size of the adductor muscle of the three species of Pen shell.

\section{References}

Anonymous,2003. Fan Shells, Family Pinnidae. Online Guide to Check Jawa. http://www.wildsingapore.com/chekjawa/text/s411.htm: (26/9/2005).

Beer, A.C. \&P.C. Southgate, 2006. Spat collection, growth and meat yield of Pinna bicolor(Gmelin) in suspended culture in northern Australia. Aquaculture, 258: 424-429

Bruyne R H D E., 2003. The complete Encyclopdia of shell, International B.V., Lisse, pp:336.

Butler, A.J.\& M.J. Keough, 1981. Distribution of Pinna bicolor Gmelin (Mollusca:Bivalvia) in South Australia with observation on recruitment. Transactions of the Royal Society of Australia; 105: 29-39. Butler, A.J. 1987. Ecology of Pinna bicolor Gmelin (Mollusca: Bivalvia) in Gulf St Vincent, South Australia: Density, reproductive cycle, recruitment, growth and mortality at three sites. Australian Journal of Marine and Freshwater Research,38: 743-769.

Dietl G,\& R.R. Alexander, 2005. High frequency and severity of breakage-induced shell repair in western Atlantic Pinnidae (Bivalvia). Journal of Molluscan Studies71: 307-311 
Sustainability, Agri, Food and Environmental Research, 2015, 3(1): 17-25

ISSN: 0719-3726

Lamprell, K. \&T. Whitehead, 1992. Bivalves of Australia. Vol. 1. Bathurst: Crowford HousePress, $182 \mathrm{p}$.

Luc Solandt, J. 1999. Fan Mussel (Atrina fragilis) current status. UK Biodiversity Group. Tranche 2 Action Plans, Maritime species and habitats. 5: 1-63.

http://www.ukbap.org.uk/UKPlans.aspx?ID=123.

Munguia, P. 2004. Successional patterns on pen shell communities at local and regional scales. Journal of Animal Ecology, 73: 64-74.

Peter Dance .S.1992, Shells Dorling Kindersley Ltd. London.

Ramakrishna \& A. Day., 2010. Annotated checklist of Indian Marine Molluscs (Cepholopoda, Bivalvia and Scaphopoda) Part 1.357 x XLIV pp.

Richardson C.A., H. Kennedy, C.M. Duarte, D.P. Kennedy\& S.V.Proud, 1999. Age and growth of the fan mussel Pinna nobilis from south-east Spanish Mediterranean seagrass (Posidonia oceanica) meadows. Marine Biology, 133: 205-212.

Rosewater, J. 1961. The Family Pinnidae in the Indo-Pacific. Indo-Pacific Mollusca 1: 175-226.

Scheltema, A., 1983. Pinna deldotesManke. Newly described and differentiated from $P$. bicolorGemilin (Bivalvia, Pterioida) Journal of the Malacological Society of Australia 6: 37-52.

Torigoe, K. 1985. Two types of Atrina (Servatirina) pectinata (Linne, 1767). Special Publication Mukaishima Marine Biology Station: 67-72.

Turk, S.M., 1982. The silkworm of the sea, spinner of cloth of gold. ConchologicalNewsletter, 83: 3942.

Velasco, C.F., 1998. The effect of tidal height and stocking density on growth of Atrina Maura Sowerby, 1835, cultured in bottom plots. Bulletin ofthe Malacological Society of London, 31: 10-12.

Wang, Z.R., 1964. Preliminary studies on Chinese Pinnidae. Studia Marina Sinica, 5: 131-141.

Yokogawa, K. 1996. Genetic divergence in two forms of pen shell Atrina pectianta. Venus 55: 25-39.

Yonge, C.M. 1953. From and habit in Pinna carnea Gmelin. Philosophical Transactions of theRoyal Society of London B 237: 335-374.

Yu, X.; Mao, Y.; Wang, M., Zhou, L.,\& J. Gui, 2004. Genetic heterogeneity analysis and RAPD marker detection among four forms of Atrina pectinata Linnaeus.Journal of Shellfish Research.23: 165-171.

Zavodnik, D., Hrs-Brenko, M. \&M. Legac, 1991. Synopsis on the fan shell Pinna nobilis L. in the eastern Adriatic Sea. In Les Especes Marines a Proteger en Mediterranee, edited by C.F. Boudsouresque, M. Avon and V. Gravez, Marseille, France. GIS Posidonie publ. 